\title{
Advances in Color Science: From Retina to Behavior
}

\author{
Bevil R. Conway, ${ }^{1,2}$ Soumya Chatterjee, ${ }^{2}$ Greg D. Field, ${ }^{3}$ Gregory D. Horwitz, ${ }^{4}$ Elizabeth N. Johnson, ${ }^{6}$ Kowa Koida, ${ }^{7}$ \\ and Katherine Mancuso ${ }^{5}$ \\ ${ }^{1}$ Neuroscience Program, Wellesley College, Wellesley, Massachusetts 02481, 2Department of Neurobiology, Harvard Medical School, Boston, Massachusetts \\ 02115, ${ }^{3}$ Systems Neurobiology Laboratories, Salk Institute for Biological Studies, La Jolla, California 98037, Departments of ${ }^{4}$ Physiology \& Biophysics, and \\ ${ }^{5}$ Ophthalmology, University of Washington, Seattle, Washington 98195, ${ }^{6}$ Duke Institute for Brain Sciences, Duke University, Durham, North Carolina \\ 27708, and 7Toyohashi University of Technology \& National Institute for Physiological Sciences, Okazaki, Aichi 444-8585, Japan
}

Color has become a premier model system for understanding how information is processed by neural circuits, and for investigating the relationships among genes, neural circuits, and perception. Both the physical stimulus for color and the perceptual output experienced as color are quite well characterized, but the neural mechanisms that underlie the transformation from stimulus to perception are incompletely understood. The past several years have seen important scientific and technical advances that are changing our understanding of these mechanisms. Here, and in the accompanying minisymposium, we review the latest findings and hypotheses regarding color computations in the retina, primary visual cortex, and higher-order visual areas, focusing on non-human primates, a model of human color vision.

In trichromatic primates, including humans and Old World monkeys, there are three types of cone photoreceptors that are responsible for color vision (Fig. $1 A, B$ ). The cone classes are called L, M, and S because of their spectral-sensitivity peaks, which lie in the long-, middle-, and short-wavelength regions of the visible spectrum. These labels replace the misleading terms "red," "green," and "blue." Two physically distinct stimuli appear as different colors only if they produce different relative activations in at least two cone types; conversely, any pair of physically distinct stimuli that activate the cone types in the same relative amount appear the same, like the two yellows shown in Figure $1 C$. While photoreceptor responses are easily computed from the spectral distribution of the stimulus, there is no straightforward relationship between photoreceptor response and color (Hofer et al., 2005a; Shevell and Kingdom, 2008). The multitude of color phenomena, including color afterimages, color assimilation, neon-color spreading, color constancy, and colored shadows, is compelling because in many cases two physically identical stimuli are made to appear different colors, or two physically different stimuli are made to appear the same simply by changing the spatial or temporal context (Fig. 2). A full description of the neural machinery for color should account for these observations, as well as more cognitive phenomena involving the rela-

Received Aug. 18, 2010; revised Sept. 22, 2010; accepted Sept. 23, 2010.

This work was funded by National Science Foundation Grant 0918064, a Whitehall Foundation Award (B.R.C.), and a Raddliffe Institute of Advanced Study Fellowship (B.R.C.); a McKnight Foundation Scholar's Award and National Institutes of Health (NIH)-National Eye Institute (NEI) Grant EY018849 (G.D.H); the Helen Hay Whitney Foundation, NIH Grant EY13150, and NSF Grant PHY-0750525 (G.D.F.), NIH Grants R01EY016861, P30EY01730, and RR00166 (K.M.); Research to Prevent Blindness (K.M.); NIH Grants P30 EY12196 and F32 EY016287 (S.C.); and Japanese Grant-in-Aid for Scientific Research 16300103, Grant for Scientific Research on Priority Areas 17022040, and Japanese MEXT Grant-in-Aid for Young Scientists 20700299 (K.K.).

All authors contributed equally to this work.

Correspondence should be addressed to Bevil R. Conway, Neuroscience Program, Wellesley College, 106 Central Street, Wellesley, MA 02481.E-mail:bconway@wellesley.edu.

DOI:10.1523/JNEUROSCI.4348-10.2010

Copyright $\odot 2010$ the authors $\quad 0270-6474 / 10 / 3014955-09 \$ 15.00 / 0$ tionship between experience, language, memory, emotion and color. The neural basis of color has been reviewed previously from a range of perspectives (Gegenfurtner, 2003; Gegenfurtner and Kiper, 2003; Lennie and Movshon, 2005; Sincich and Horton, 2005; Solomon and Lennie, 2007; Conway, 2009; Dobkins, 2009; Jacobs and Nathans, 2009; Stockman and Brainard, 2010). Here we focus on advances and pressing questions regarding the mechanisms of color in retina, striate cortex, and extrastriate cortex of non-human primates, although we note that other species are emerging as excellent model systems of color processing (Lotto and Chittka, 2005; Van Hooser and Nelson, 2006; Osorio and Vorobyev, 2008; Borst, 2009; Johnson et al., 2010; Srinivasan, 2010).

\section{Retinal mechanisms}

A single cone by itself is color blind because its activation depends on both the wavelength(s) and intensity of the stimulus. A comparison of the signals from different classes of photoreceptors is therefore the most basic computational requirement of a colorvision system. The existence of cone-opponent retinal ganglion cells that perform such comparisons is well established in primate (Dacey and Packer, 2003; Jacobs, 2008). Cone-opponent retinal ganglion cells respond with increased firing to an increment in activation of one cone type (on-response) and to a decrement in activation of a different cone type (off-response) (De Monasterio et al., 1975; Dacey and Lee, 1994). Cone-opponent retinal ganglion cells come in four varieties: L-on/M-off, M-on/L-off, S-on/ $(\mathrm{L}+\mathrm{M})$-off, and $(\mathrm{L}+\mathrm{M})$-on/S-off, although the receptive fields of ON cells often have markedly different sizes and temporal dynamics compared with OFF cells, especially for cells receiving strong S-cone input (Chichilnisky and Kalmar, 2002; Chatterjee and Callaway, 2003; Conway and Livingstone, 2006; Tailby et al., 2008; Field et al., 2010). The four varieties of retinal ganglion cells were originally thought to underlie the psychological finding of four unique hues (red, green, blue, and yellow) that are yoked by 
A
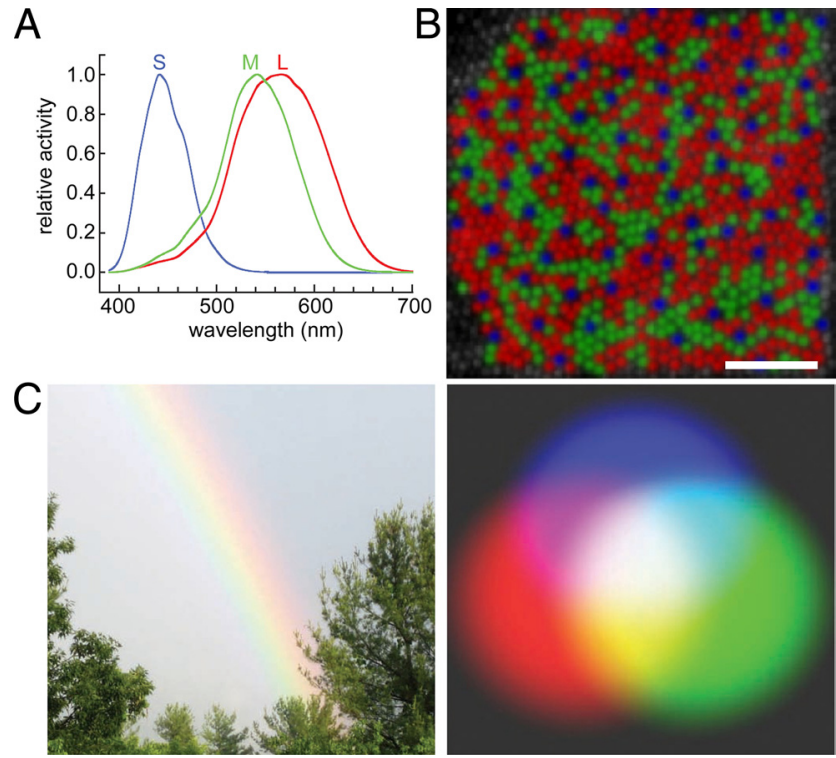

Figure 1. First stages of color. $A$, Spectral sensitivity functions of the three cone types in trichromatic primates (adapted with permission from Stockman and Brainard, 2010). B, Falsecolored representation of the cone mosaic of a macaque monkey (scale bar, $0.2^{\circ}$ ); adapted from Roorda et al. (2001). C, Rainbow showing monochromatic yellow (left) and additive color mixing of lights showing mixed yellow (right).

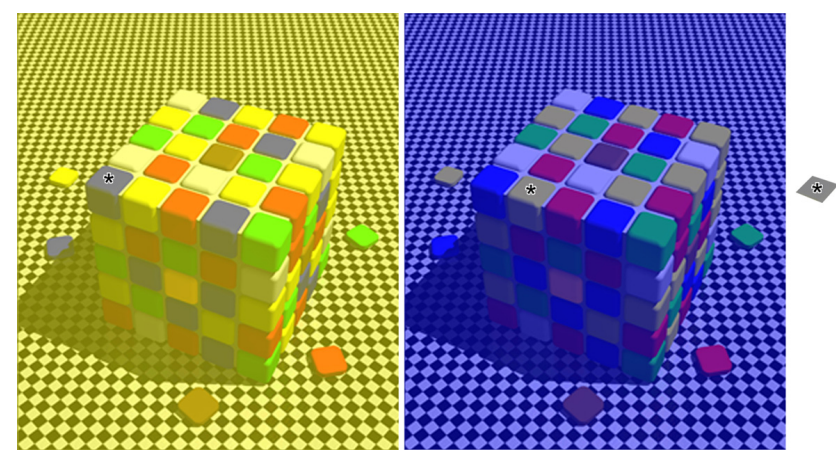

Figure 2. Spatial color contrast changes color appearance. The patches indicated by the asterisk are all physically identical. Image courtesy of Beau Lotto (University College London, London, UK).

perceptual antagonism (red is exclusive of green; blue is exclusive of yellow). But this simple relationship of retina physiology to psychology turns out not to be true (Derrington et al., 1984; Valberg, 2001; Webster, 2009); still, cone-opponent cells are often referred to by color terms. The neural basis for the unique hues remains elusive, although responses in extrastriate cortex may provide some clues (see last section). Two major open questions regarding retinal color processing are the nature and diversity of the neural circuitry that produces cone-opponent responses and the relationship between retinal physiology and color perception.

\section{L-M opponent cell types and circuitry}

Morphologically defined $\mathrm{ON}$ and OFF midget cells project to the parvocellular layers of the lateral geniculate nucleus (LGN) - the LGN is the thalamic nucleus that connects retina and visual cortex. Both midget and parvocellular cells show $\mathrm{L}$ versus $\mathrm{M}$ coneopponent responses that result from spatially opponent centersurround receptive fields (Fig. $3 A$ ). It has been difficult to determine whether midget cell centers and/or surrounds selectively or randomly sample from L and $\mathrm{M}$ cones (Martin et al.,
A
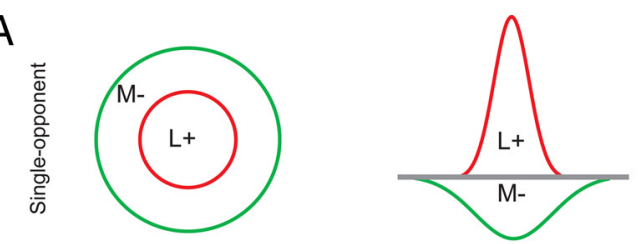

B
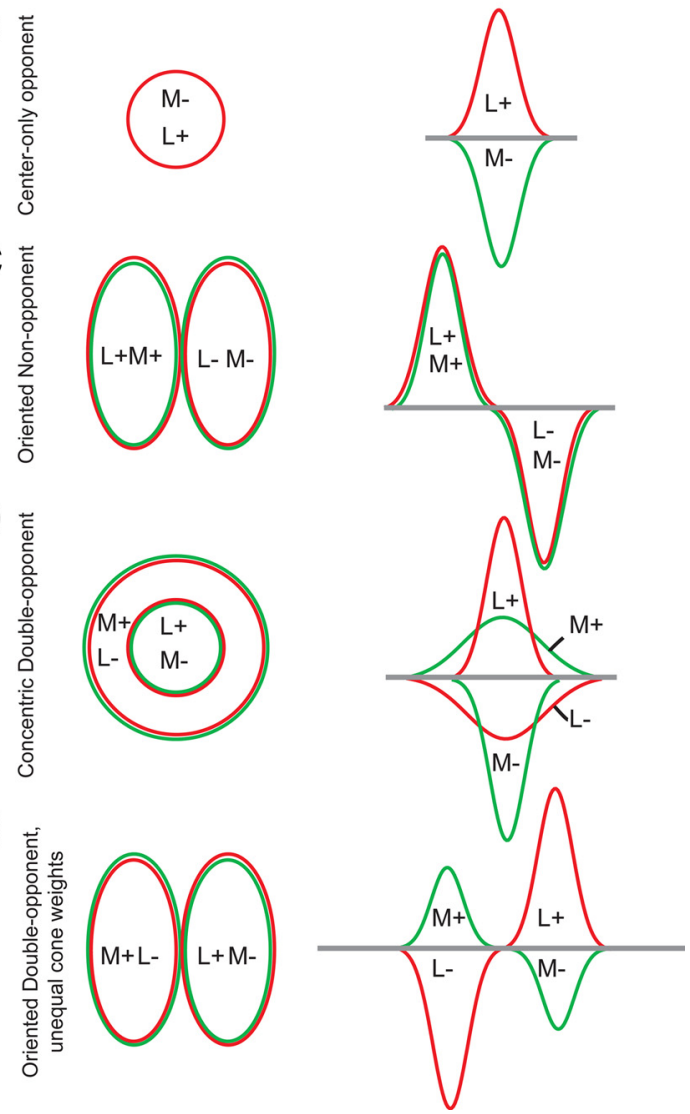

Figure 3. Diagrams of various model receptive fields. Top view (left), side view (right). See sections " $L-M$ opponent cell types and circuitry" and "How are the cone cells transformed by V1?" for details.

2001; Diller et al., 2004; Buzás et al., 2006; Jusuf et al., 2006; Field et al., 2010). At one extreme, the center and surround could exclusively sample different cone types (e.g., the center samples only $\mathrm{M}$ cones, and the surround samples only L cones) (Wiesel and Hubel, 1966; Reid and Shapley, 2002). At the other extreme, $\mathrm{L}$ and $\mathrm{M}$ cones could be randomly sampled by center and surround, with cone-opponent responses occurring in some cells by chance (Lennie et al., 1991; Billock, 1996).

Near the fovea, midget cell receptive-field centers selectively sample from a single cone type for a trivial reason: they are fed by a single cone (Kolb and Marshak, 2003). But even foveal midget cells might have centers that are impure because gap junctions could mix signals between L and M cones (Hornstein et al., 2004). The degree of cone selectivity of midget cell surrounds near the fovea is also unclear. While physiological studies have suggested at least some selective cone sampling (Reid and Shapley, 2002; Buzás et al., 2006), anatomical studies have found little evidence for cone-selective circuitry (Wässle et al., 2000; Dacey and Packer, 2003). Questions remain about selectivity of the surround because stimulating the surround in isolation of the center is difficult and the relative contribution to the surround from horizontal cells versus amacrine cells remains unclear (Mangel, 
1991; Cook and McReynolds, 1998; Ichinose and Lukasiewicz, 2005; Davenport et al., 2008).

In the peripheral retina, where both the center and surround of midget cells sample from multiple cones, the cone purity has been similarly controversial (Martin et al., 2001; Jusuf et al., 2006). A recent study using receptive-field mapping at the resolution of single cones found small but consistent deviations from random toward selective sampling in the receptive-field center, but not in the surround (Field et al., 2010). The mechanism and anatomical basis for this selectivity is uncertain. One might wonder whether spatial clumping of $\mathrm{L}$ and $\mathrm{M}$ cones by type could contribute (Roorda et al., 2001; Hofer et al., 2005b) (Fig. 1 B), but recent evidence suggests the contribution of cone clumping is minor (Field et al., 2010).

Do midget cells form the basic building blocks for the "redgreen" color-vision circuit? Many investigators assume so, although the mismatch between the high density of midget cells and the relatively low spatial acuity for color has raised some doubts (Hubel and Livingstone, 1990; Calkins and Sterling, 1999). Parasol cells can show L-M cone-opponent responses (Derrington et al., 1984; Lee and Sun, 2009), so they could play some role in color vision, though this is controversial. Additionally, one of the many morphologically defined "wide-field" retinal ganglion cells with low density may encode L-M opponent responses that contribute to color vision (Dacey and Packer, 2003); these cells may correspond to the still elusive red-green type II cells alluded to by Wiesel and Hubel (1966) in their recordings of neurons located in the intercalated, or koniocellular ("K"), layers that separate the main layers of the LGN (Fig. 3B).

$S$ versus $L+M$ opponent cell types and circuitry

There are several types of retinal ganglion cells that oppose $S$ signals against $\mathrm{L}+\mathrm{M}$. The small bistratified cell was the first morphologically identified "blue-yellow" cell (Dacey and Lee, 1994; Dacey and Packer, 2003), but there are others: the large bistratified and giant monostratified cells (Dacey et al., 2003, 2005). These cell types project to the koniocellular layers of the LGN (Szmajda et al., 2008; Roy et al., 2009). In addition, OFF (but not $\mathrm{ON}$ ) midget cells in the central and peripheral retina also appear to carry S cone signals to the brain (Klug et al., 2003; Field et al., 2010; but see Lee et al., 2005; Sun et al., 2006). Unfortunately, the role of $S$ versus $\mathrm{L}+\mathrm{M}$ opponent retinal ganglion cells in blueyellow color vision is all but clear (Derrington et al., 1984).

The circuitry producing cone-opponent responses in small bistratified cells differs from that of midget cells (Dacey and Lee, 1994; Crook et al., 2009). Small bistratified cells have dendrites in two distinct strata of the inner plexiform layer. The inner dendrites receive input from ON-type bipolar cells that synapse exclusively with $\mathrm{S}$ cones. The outer dendrites receive input from off-type bipolar cells (Calkins et al., 1998; Grünert and Ghosh, 1999; Percival et al., 2009) that carry L and M cone signals. In far peripheral retina and/or under low photopic conditions, the $\mathrm{H} 2$ horizontal cell may also contribute to the $(\mathrm{L}+\mathrm{M})$-off response (Field et al., 2007; Packer et al., 2010). Large bistratified cells probably have a circuitry similar to that of small bistratified cells (Dacey et al., 2003), and the circuitry of giant monostratified cells is yet to be determined.

Our understanding of the retinal mechanisms of color is far from complete. The response properties of all $\sim 20$ retinal ganglion cell types need to be characterized to identify those with cone-opponent responses. Also, the roles of excitation and inhibition in the inner and outer synaptic layers need to be clarified to understand how retinal circuitry produces cone opponency. Finally, more studies are

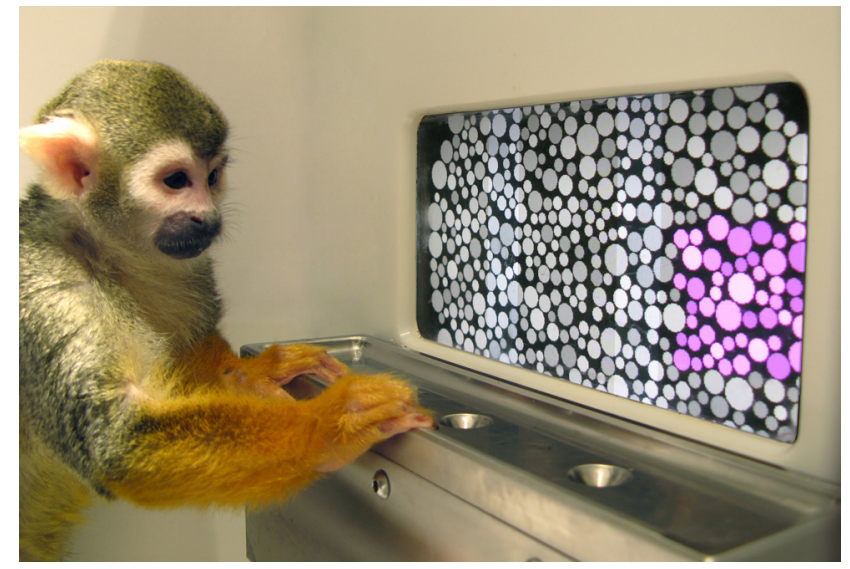

Figure 4. Squirrel monkey performing a trichromatic color discrimination following gene therapy. Image courtesy of the Neitz laboratory.

needed that quantitatively probe the relationship between retinal signals and color perception (Derrington et al., 1984; Kremers et al., 1992).

\section{Retinal gene therapy}

Unlike Old World monkeys, most mammals are dichromats. New World monkeys, such as squirrel monkeys, have color vision that is an evolutionary intermediate between dichromats and trichromats (Jacobs, 2008). Instead of having L and M cone opsin genes, like humans and Old World monkeys, each New World monkey has only a single X-chromosome opsin locus containing one of multiple alleles (Neitz et al., 1991). Males have only one $\mathrm{X}$-chromosome, so all New World male monkeys are dichromats. Heterozygous females who inherit different $\mathrm{M} / \mathrm{L}$ alleles on each $\mathrm{X}$-chromosome express the pigments in different cone populations due to random $\mathrm{X}$-inactivation, producing trichromacy in two thirds of females. Normal dichromatic and normal trichromatic color vision coexist in these species, and the brain circuitry for both is specified by the same genetic instructions. The ancestors to humans and other Old World primates must have passed through an evolutionary stage in which the distribution of dichromats and trichromats was similar to the New World primates. Thus a single set of genetic instructions serves both dichromacy and trichromacy, raising the possibility that no additional changes were required besides the addition of a third cone opsin. This would account for the observation that transgenic mice, engineered to express three cone pigments, can show behavioral trichromacy (Jacobs et al., 2007).

But does the red-green color-vision circuit require early visual experience to become functional? This question was addressed using gene therapy to add a third photopigment to the retinas of adult dichromatic squirrel monkeys (Mancuso et al., 2009). Remarkably, this simple intervention was sufficient to confer trichromatic color vision (Fig. 4). Because new color vision behavior corresponded in time to the appearance of robust transgene expression levels, it seems that significant "rewiring" in the adult is not required. This result suggests that red-green color vision can be added by taking advantage of preexisting neural circuitry (Mancuso et al., 2009; Shapley, 2009), that an early developmental process is not required, and that trichromacy could have evolved in the absence of any other change in the visual system except the addition of a third cone type (Mancuso et al., 2010a).

The treated animals made all the usual discriminations made by animals born with the genetic potential for trichromacy. They discriminate reds from greens, and these colors from gray; and 
they do not confuse blue and yellow with either red or green (Mancuso et al., 2010b). Thus, while the treated animals' internal experiences associated with stimulation of their new cone type remain unknown, it is clear that reds, greens, blues, and yellows are recognized as distinct sensations. This discovery opens interesting questions concerning the role of development and experience in sculpting circuitry that mediates perception, including properties of the visual system that enable a new capacity to be added after traditional critical periods have ended.

\section{Striate cortex mechanisms}

The cortical area that receives the largest projection from the LGN is primary visual cortex, also called V1 or striate cortex. Three outstanding questions continue to drive research into color processing in V1: Which neurons code color? How are the cone signals transformed by V1? And, is there a functional architecture for color in $\mathrm{V} 1$ ?

\section{Which V1 cells code color?}

Early investigations found that many V1 neurons are tuned for the orientation and spatial frequency of black-and-white patterns (Fig. 3C), with few strongly selective for color (Hubel and Wiesel, 1968; Schiller et al., 1976). The smaller population of strongly color-selective neurons, studied using broadband (white) light passed through colored filters, could be classified like LGN cells in red/green or blue/yellow categories (Dow and Gouras, 1973; Gouras, 1974; Michael, 1978; Livingstone and Hubel, 1984; Vautin and Dow, 1985; Ts'o and Gilbert, 1988). These observations motivated the influential idea that color is processed by a specialized subsystem that can be traced from retina to V1 (Livingstone and Hubel, 1984).

But could the observation of distinct neuronal "types" (red/ green and blue/yellow; color-coding and non-color-coding) in these early studies be an artifact of the small set of stimuli used? Neurons that responded similarly to the colors tested might have been distinguished if tested with an alternate set, or a larger battery of colors. In subsequent experiments, cathode ray tube monitors made it easy to present millions of colors, although only a small subset of these could be included in an experiment of realistic duration. Investigators needed a way to summarize color tuning succinctly and in a way that did not make assumptions about the number and types of chromatically distinct subpopulations present.

An important step was made by Derrington et al. (1984), who found that the response of an LGN neuron to any stimulus could be predicted from a weighted sum of activity modulations in the three cone types. This critical finding - that the LGN responses are "linear"-meant that color tuning could be described concisely with a set of three numbers, which are the weights applied to input from the three cone classes. On the basis of these cone weights, each LGN neuron could be assigned unambiguously to one of three clusters, providing justification for the classification originally described by De Valois et al. (1966).

The cone weights of V1 neurons, however, appear to form a continuum (Lennie et al., 1990; De Valois et al., 2000; Johnson et al., 2004; Solomon et al., 2004; Solomon and Lennie, 2005; Horwitz et al., 2007). Chromatic signals from the LGN thus appear to be mixed in V1 in myriad, perhaps arbitrary ways. But the analysis of V1 cone weights is problematic in two key respects. First, cone weights do not indicate the degree to which a neuron is color selective; it remains possible that only the most color-selective neurons relay color signals in V1 (Conway, 2001; Johnson et al., 2001; Wachtler et al., 2003; Horwitz et al., 2007). Second, the concept of a "cone weight" is only meaningful if the response of a V1 neuron can be adequately described as a weighted sum of cone inputs. This assumption has come under scrutiny. Hanazawa et al. (2000) described V1 neurons whose color tuning was too sharp to result from a linear combination of cone signals. Solomon et al. (2005) found that a divisive signal from the cones contributed significantly to the responses of some V1 neurons, and Horwitz et al. (2005) found that the responses of some coneopponent V1 neurons were facilitated by luminance signals, which indicates a violation of linearity.

There is now consensus that many V1 neurons do not combine cone signals linearly, so we should not be surprised that analyses of cone weights give results that are difficult to interpret. We are now forced to reevaluate the original questions: which cells in V1 code color, and might there be a specialized pathway for color processing in V1? Much of the evidence against this idea was based on the fit of a model that describes the color tuning of V1 neurons incompletely (Hanazawa et al., 2000; Solomon and Lennie, 2005; Horwitz et al., 2007). An important future direction is to revisit this question in a way that that makes fewer assumptions about how V1 neurons combine cone inputs.

\section{How are the cone signals transformed by V1?}

Color contrast makes red appear redder when surrounded by green, while color constancy enables an object's color to remain largely constant as the illuminant changes (see Fig. 2). A flurry of attention has been paid to mechanisms in V1 that may be responsible for these, and other, color-form interactions (Zhou et al., 2000; Gegenfurtner, 2001; Shapley and Hawken, 2002; Friedman et al., 2003; Hurlbert, 2003, 2007; Kiper, 2003; Wachtler et al., 2003). This work has both reinvigorated and challenged the idea that color, or some aspect of it, may be handled by a specialized pathway.

The early discoveries of Hubel and Wiesel (1968) left a paradox: if "form" is encoded by a discrete population of color-blind neurons, and "color" information by a separate population of form-blind neurons, how does the brain encode color-form interactions required to account for color contrast and color constancy? Single-opponent cells (Fig. 3A) would be incapable of color-contrast calculations because they are not spatially selective for color: an "L-ON/M-OFF" single-opponent cell responds well to spots, bars, or a full field of red, but not to a red spot on a green background. One possible mechanism for encoding colorform interactions is through specialized "double-opponent" cells (Fig. 3D), first described in goldfish retina (Daw, 1967). Pressing questions have centered on the existence, characterization, and wiring of such cells in primate V1.

To carry information expressly about color boundaries, it was hypothesized that double-opponent cells in V1 would have perfectly balanced cone inputs and concentrically organized centers and surrounds (Michael, 1978; Livingstone and Hubel, 1984). Such a cell would respond to a red spot on a green background, and not to luminance spots of any size. The concentric organization of their receptive fields would also mean that they would be spatially tuned, but not orientation selective. Double-opponent neurons fitting this description were reported in a few early studies (Hubel and Wiesel, 1968; Michael, 1978; Livingstone and Hubel, 1984), but other studies with large samples of V1 cells found little evidence of them (Thorell et al., 1984; Lennie et al., 1990).

New neurophysiological evidence shows that there is a significant population of double-opponent cells in V1, although these cells do not have all the originally hypothesized receptive-field properties. The inputs to these cells are spatially segregated by cone type into excitatory and inhibitory receptive-field subunits 


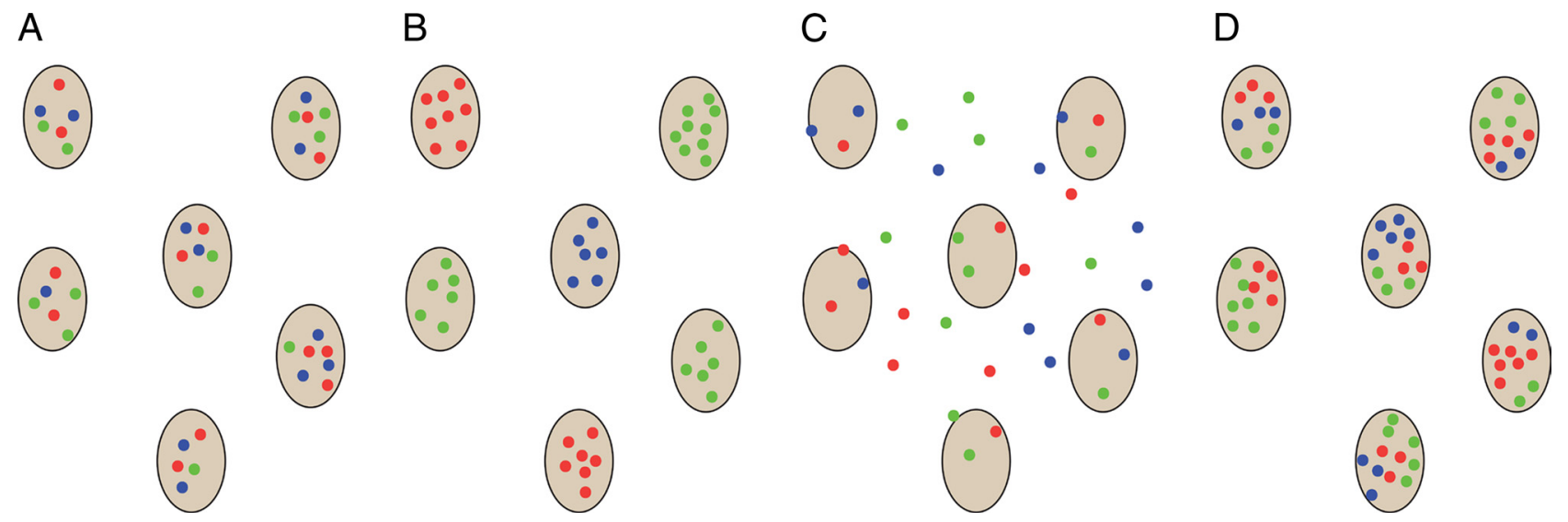

Figure 5. Alternative models for the organization of color-tuned neurons in V1. The gray patches depict cytochrome-oxidase blobs. Dots show color-tuned neurons that are clustered in blobs, but mixed randomly within each blob $(\boldsymbol{A})$; clustered in blobs, and segregated according to color tuning within pure-color blobs $(\boldsymbol{B})$; randomly arranged with respect to blobs $(\boldsymbol{C})$; and clustered within blobs and according to a micromap in which cells of similar tuning are adjacent within a given blob (D).

(Conway, 2001; Johnson et al., 2001, 2004, 2008; Conway et al., 2002; Conway and Livingstone, 2006), verifying that these neurons are both color-opponent and spatially opponent, but the cells frequently lack a concentric center-surround organization. Many double-opponent cells also respond to both color and luminance (Thorell et al., 1984; Conway, 2001; Johnson et al., 2001, 2004, 2008; Conway and Livingstone, 2006; Horwitz et al., 2007).

A growing body of evidence shows that many doubleopponent neurons are orientation-selective for both color and achromatic patterns, regardless of the constitution of cone input (Thorell et al., 1984; Conway, 2001; Johnson et al., 2001, 2008, 2010; Conway et al., 2002; Heimel et al., 2005; Conway and Livingstone, 2006; Horwitz et al., 2007). This transformation means that these cells respond to cues for form, such as boundaries and edges, and may take signals from color or black and white as needed. Neurophysiological evidence that V1 neurons can be both color-selective and orientation-selective is consistent with recent functional magnetic resonance imaging (fMRI) and psychophysical studies in humans showing orientation-selective responses to color stimuli (Beaudot and Mullen, 2005, 2006; Engel, 2005; Huang et al., 2007; Sumner et al., 2008). The differences from the originally proposed double-opponent cell necessitate a revision of the model (Fig. 3E).

Color likely depends on both single-opponent and doubleopponent neurons, and on the further processing of their signals (Vladusich, 2007). Single-opponent cells would seem ideal for signaling the color of a region covering the receptive field, while double-opponent cells would be capable of signaling color contrast, color boundaries and edges, and contributing to color constancy. Future directions will involve developing rigorous methods to test these predictions, building physiologically relevant computational models, and establishing the extent to which these populations of neurons represent a distinct specialized pathway.

\section{Is there a functional organization for color in V1?}

Columns of cells with similar orientation tuning extend down through the vertical thickness of $\mathrm{V} 1$, and the orientation tuning of adjacent columns shifts gradually across the horizontal surface (Hubel and Wiesel, 1977), an architecture that has become more precisely understood as technology has advanced (Blasdel and Salama, 1986; Grinvald et al., 1986; Ohki et al., 2006). Pinning down the functional organization of color in V1 has been more challenging. The laminar projection of color-opponent signals from LGN to V1 seems clear: L-M signals target the middle input layer $(4 \mathrm{C} \beta), \mathrm{S}-(\mathrm{L}+\mathrm{M})$ ("Blue $\mathrm{ON}$ ") signals target the upper input layers (2/3 and $4 \mathrm{~A})$, and ( $\mathrm{L}+\mathrm{M})-\mathrm{S}$ ("Blue OFF") signals are narrowly stratified in 4A (Lachica and Casagrande, 1992; Martin et al., 1997; Hendry and Reid, 2000; Chatterjee and Callaway, 2003; Casagrande et al., 2007). But there is no consensus on the horizontal organization of chromatic signals within V1. Livingstone and Hubel (1984) showed that color cells tend to coincide with regions, called blobs, that stain for the enzyme cytochrome oxidase (Fig. 5A); this view was extended by Ts'o and Gilbert (1988), who suggested that some blobs were entirely red/green and others entirely blue/yellow (Fig. 5B). But subsequent electrophysiological studies (Lennie et al., 1990; Leventhal et al., 1995; Friedman et al., 2003) called this architecture into question, suggesting no obvious clustering of color and no functional architecture related to blobs (Fig. 5C).

These contradictory results may not be surprising given the sampling limitations of extracellular recording and the challenge of aligning physiological recording sites with postmortem histochemical analysis. Intrinsic signal imaging, with its bird's-eye view of the cortical surface, rekindled the notion of color maps organized according to blobs. Landisman and Ts'o (2002) concluded that color-responsive regions are loosely associated with blobs, and that these regions are joined by color "bridges" spanning adjacent blobs. Using a similar approach, Lu and Roe (2008) concluded that there is a tighter association between colorresponsive regions and blobs. Finally, a recent optical-imaging study, which unfortunately did not provide histology, concluded that color is functionally organized as an array of hue maps, with each map containing a representation for multiple colors at overlapping but slightly different spatial locations (Xiao et al., 2007). The low resolution of intrinsic optical imaging, however, makes it impossible to determine how the signals map onto individual cells within neuronal ensembles.

The question of color architecture has been approached using two-photon calcium imaging, which enables the activity of thousands of individual cells to be measured simultaneously. Preliminary results suggest that cone-opponent cells form clusters, and that these clusters are in register with blobs (Chatterjee et al., 2008). The clusters appear to extend through upper layer $2 / 3$, forming columns of chromatic selectivity. Moreover, these color columns appear to be subdivided into regions of different chromatic signatures, suggesting a "micromap" model (Fig. 5D) that 
helps to explain discrepancies in previous observations of color architecture. These two-photon imaging results reveal a precise functional architecture for color and support the notion that V1 color signals are processed by an anatomically segregated pathway, which may provide the basis for a segregated output to extrastriate areas of the ventral stream.

Two-photon imaging allows the responses of hundreds of neurons to be measured simultaneously; but, as discussed in the previous sections, V1 neurons show variety in spatial and temporal receptive-field organization, and many do not combine cone signals linearly. In the face of this heterogeneity, it is not trivial to determine stimulus parameters that would be suitable to adequately assess color tuning using two-photon imaging. It will be important, in future work, to establish whether two-photon imaging can provide an accurate measure of color tuning, perhaps by directly comparing measurements with those obtained using single-unit recording.

\section{Extrastriate cortex mechanisms}

One heuristic of color processing (Fig. 6) holds that color signals are transmitted along the ventral visual stream, from V1 through subcompartments of $\mathrm{V} 2$ referred to as the thin stripes (because of their pattern of staining with cytochrome oxidase), on to islands of cortex dubbed "globs" located in V4 and posterior inferior temporal cortex (PIT), and ultimately on to inferior temporal cortex (IT) (Desimone et al., 1985; Komatsu, 1998; Zeki and Marini, 1998; Conway et al., 2007; Matsumora et al., 2008; Harada et al., 2009; Yasuda et al., 2010). This simple hierarchical model suggests that many color computations take place downstream of V1. But compared with our understanding of retina and V1, we know little about how extrastriate cortex contributes to color. Recent work using microelectrodes and fMRI-guided microelectrode recordings has opened up new questions at the interface of neurobiology and behavior (Conway et al., 2007; Koida and Komatsu, 2007; Matsumora et al., 2008; Stoughton and Conway, 2008; Conway and Tsao, 2009).

IT is located in the temporal lobe of the monkey (anterior to the ears), and can be divided into two parts (Iwai and Mishkin, 1969): area TE, which includes anterior and central IT, and area TEO, which includes PIT (Van Essen et al., 1990). The posterior boundary of PIT adjoins area V4, although the boundary is imprecise-indeed the boundaries of all visual areas in the temporal lobe are provisional (Brewer et al., 2002; Fize et al., 2003; Tootell et al., 2004; Stepniewska et al., 2005). Several studies have shown that lesions or cooling of area TE impairs color discrimination (Dean, 1979; Horel, 1994; Heywood et al., 1995; Buckley et al., 1997), whereas lesions of other color-related areas (PIT and V4) cause little disruption in color discrimination (Heywood et al., 1998; Huxlin et al., 2000). In humans, rare lesions of ventral occipital cortex can produce colorblindness, while sparing other visual function (Bouvier and Engel, 2006), but the relationship of these regions, whose activity can be used to decode color (Brouwer and Heeger, 2009), to extrastriate regions in macaque monkey remains controversial (Hadjikhani et al., 1998; Tootell and Hadjikhani, 1998; Zeki et al., 1998). Brain imaging, which has a higher resolution in monkeys than in humans owing to the use of contrast agents and the monkey's smaller head, suggests that color is handled by area TE along with a distributed network of globs within PIT/V4, rather than a single entire extrastriate visual area (Conway and Tsao, 2006; Conway et al., 2007; Harada et al., 2009); this is consistent with anatomical and optical-imaging data (Zeki and Shipp, 1989; DeYoe et al., 1994; Felleman et al., 1997; Ghose and Ts'o, 1997).

Neural recording studies have shown that many neurons in IT respond selectively to color (Zeki, 1980; Desimone et al., 1984; Komatsu et al., 1992; Komatsu and Ideura, 1993; Kobatake and Tanaka, 1994; Koida and Komatsu, 2007; Matsumora et al., 2008). These neurons are narrowly tuned to color and color saturation, and are concentrated in several subregions of IT, one located in TE and another in TEO (Conway et al., 2007; Yasuda et al., 2010). Neurons in TE show relatively weak shape selectivity (Matsumora et al., 2008), while neurons in the more posterior region show stronger shape selectivity (Conway et al., 2007; Yasuda et al., 2010).

The relationship between color perception and neuronal activity of anterior IT has recently been examined by Matsumora et al. (2008), who showed a significant correlation between the trialto-trial fluctuations in neuronal responses of color-tuned neurons and the monkeys' color judgment. They also found that the variation in neural threshold across the color space corresponded well with that of the behavioral threshold. Electrical stimulation of this region induces a large shift in the monkey's color judgment, suggesting that neural activities are causally related to color judgment (Koida and Komatsu, 2008). Such a causal link is also suggested by recent microstimulation experiments in human subjects (Murphey et al., 2008).

The ability to categorize stimuli by color is a fundamental cognitive process. The population of neurons recorded in fMRIidentified globs of posterior IT shows a bias for the most saturated colors in a stimulus set, which also correspond to the elementary, or "unique" hue categories, suggesting a neural basis for color categories (Stoughton and Conway, 2008; Conway and Stoughton, 2009; Conway and Tsao, 2009; but see Mollon, 2009). Koida and Komatsu (2007) argue that IT neurons are involved in color cognition by showing that IT neurons change firing rate when the monkey switches from a categorization to a discrimi- 
nation task; moreover, they found that a majority of neurons gave stronger responses when the animals performed a colorcategorization task versus when they performed a colordiscrimination task. Their results imply that IT neurons play an important role in color categorization.

The color-selective neurons in extrastriate regions along the ventral pathway must play an important role in color processing. With the refinement of physiological recording techniques, coupled with more sophisticated psychophysical stimulus paradigms, the specific computations performed by these neurons, the relationship of their activity to perception, and the neural circuitry that connects these cells to color cells in V1 and retina, should become clear.

\section{Conclusion}

Research using color vision as a model system has seen terrific advances, offering the hope of a complete understanding of the transformation of color signals from retina to behavior. The minisymposium that accompanies this review will showcase results that aim to understand this transformation and the circuits that bring it about. During the minisymposium, we will describe results from large retinal array recordings, in which the activity of hundreds of retinal ganglion cells is assessed simultaneously, affording the ability to measure receptive fields of color-opponent cells at the resolution of individual cones. We will go on to describe experiments exploring gene therapy for red-green colorblindness, and the implications of this research for theories of color vision. We will then describe results obtained using two-photon imaging, showing the fine-scale spatial organization of cone-opponent cells in V1. In addition, using single-unit electrophysiological recordings and twophoton imaging, we will address how V1 neurons achieve color tuning. We will also discuss the spatial transformation of color signals in $\mathrm{V} 1$ and the degree to which color is processed independently of other stimulus attributes like orientation. Finally, we will turn our attention to extrastriate regions that likely mediate the conscious experience of color, and address potential limits of animal models of human color vision. Using this knowledge, we aim to enrich our understanding of the relationship between genetics, neural circuits, perception, and behavior.

\section{References}

Beaudot WH, Mullen KT (2005) Orientation selectivity in luminance and color vision assessed using 2-d band-pass filtered spatial noise. Vision Res 45:687-696.

Beaudot WH, Mullen KT (2006) Orientation discrimination in human vision: psychophysics and modeling. Vision Res 46:26-46.

Billock VA (1996) Consequences of retinal color coding for cortical color decoding. Science 274:2118-2119.

Blasdel GG, Salama G (1986) Voltage-sensitive dyes reveal a modular organization in monkey striate cortex. Nature 321:579-585.

Borst A (2009) Drosophila's view on insect vision. Curr Biol 19:R36-R47.

Bouvier SE, Engel SA (2006) Behavioral deficits and cortical damage loci in cerebral achromatopsia. Cereb Cortex 16:183-191.

Brewer AA, Press WA, Logothetis NK, Wandell BA (2002) Visual areas in macaque cortex measured using functional magnetic resonance imaging. J Neurosci 22:10416-10426.

Brouwer GJ, Heeger DJ (2009) Decoding and reconstructing color from responses in human visual cortex. J Neurosci 29:13992-14003.

Buckley MJ, Gaffan D, Murray EA (1997) Functional double dissociation between two inferior temporal cortical areas: perirhinal cortex versus middle temporal gyrus. J Neurophysiol 77:587-598.

Buzás P, Blessing EM, Szmajda BA, Martin PR (2006) Specificity of M and L cone inputs to receptive fields in the parvocellular pathway: random wiring with functional bias. J Neurosci 26:11148-11161.

Calkins DJ, Sterling P (1999) Evidence that circuits for spatial and color vision segregate at the first retinal synapse. Neuron 24:313-321.
Calkins DJ, Tsukamoto Y, Sterling P (1998) Microcircuitry and mosaic of a blue-yellow ganglion cell in the primate retina. J Neurosci 18:3373-3385.

Casagrande VA, Yazar F, Jones KD, Ding Y (2007) The morphology of the koniocellular axon pathway in the macaque monkey. Cereb Cortex 17:2334-2345.

Chatterjee S, Callaway EM (2003) Parallel colour-opponent pathways to primary visual cortex. Nature 426:668-671.

Chatterjee S, Ohki K, Reid RC (2008) Functional micro-architecture of color selectivity in macaque primary visual cortex. Soc Neurosci Abstr 34:666.15.

Chichilnisky EJ, Kalmar RS (2002) Functional asymmetries in ON and OFF ganglion cells of primate retina. J Neurosci 22:2737-2747.

Conway BR (2001) Spatial structure of cone inputs to color cells in alert macaque primary visual cortex (V-1). J Neurosci 21:2768-2783.

Conway BR (2009) Color vision, cones, and color-coding in the cortex. Neuroscientist 15:274-290.

Conway BR, Livingstone MS (2006) Spatial and temporal properties of cone signals in alert macaque primary visual cortex. J Neurosci 26:10826-10846.

Conway BR, Stoughton CM (2009) Towards a neural representation for unique hues. Curr Biol 19:R442-R443.

Conway BR, Tsao DY (2006) Color architecture in alert macaque cortex revealed by FMRI. Cereb Cortex 16:1604-1613.

Conway BR, Tsao DY (2009) Color-tuned neurons are spatially clustered according to color preference within alert macaque posterior inferior temporal cortex. Proc Natl Acad Sci U S A 106:18034-18039.

Conway BR, Hubel DH, Livingstone MS (2002) Color contrast in macaque V1. Cereb Cortex 12:915-925.

Conway BR, Moeller S, Tsao DY (2007) Specialized color modules in macaque extrastriate cortex. Neuron 56:560-573.

Cook PB, McReynolds JS (1998) Lateral inhibition in the inner retina is important for spatial tuning of ganglion cells. Nat Neurosci 1:714-719.

Crook JD, Davenport CM, Peterson BB, Packer OS, Detwiler PB, Dacey DM (2009) Parallel ON and OFF cone bipolar inputs establish spatially coextensive receptive field structure of blue-yellow ganglion cells in primate retina. J Neurosci 29:8372-8387.

Dacey DM, Lee BB (1994) The 'blue-on' opponent pathway in primate retina originates from a distinct bistratified ganglion cell type. Nature 367:731-735.

Dacey DM, Packer OS (2003) Colour coding in the primate retina: diverse cell types and cone-specific circuitry. Curr Opin Neurobiol 13:421-427.

Dacey DM, Peterson BB, Robinson FR, Gamlin PD (2003) Fireworks in the primate retina: in vitro photodynamics reveals diverse LGN-projecting ganglion cell types. Neuron 37:15-27.

Dacey DM, Liao HW, Peterson BB, Robinson FR, Smith VC, Pokorny J, Yau KW, Gamlin PD (2005) Melanopsin-expressing ganglion cells in primate retina signal colour and irradiance and project to the LGN. Nature 433:749-754.

Davenport CM, Detwiler PB, Dacey DM (2008) Effects of pH buffering on horizontal and ganglion cell light responses in primate retina: evidence for the proton hypothesis of surround formation. J Neurosci 28:456-464.

Daw NW (1967) Goldfish retina: organization for simultaneous color contrast. Science 158:942-944.

Dean P (1979) Visual cortex ablation and thresholds for successively presented stimuli in rhesus monkeys: II. Hue. Exp Brain Res 35:69-83.

De Monasterio FM, Gouras P, Tolhurst DJ (1975) Concealed colour opponency in ganglion cells of the rhesus monkey retina. J Physiol 251:217-229.

Derrington AM, Krauskopf J, Lennie P (1984) Chromatic mechanisms in lateral geniculate nucleus of macaque. J Physiol 357:241-265.

Desimone R, Albright TD, Gross CG, Bruce C (1984) Stimulus-selective properties of inferior temporal neurons in the macaque. J Neurosci 4:2051-2062.

Desimone R, Schein SJ, Moran J, Ungerleider LG (1985) Contour, color and shape analysis beyond the striate cortex. Vision Res 25:441-452.

De Valois RL, Abramov I, Jacobs GH (1966) Analysis of response patterns of LGN cells. J Opt Soc Am 56:966-977.

De Valois RL, Cottaris NP, Elfar SD, Mahon LE, Wilson JA (2000) Some transformations of color information from lateral geniculate nucleus to striate cortex. Proc Natl Acad Sci U S A 97:4997-5002.

DeYoe EA, Felleman DJ, Van Essen DC, McClendon E (1994) Multiple processing streams in occipitotemporal visual cortex. Nature 371:151-154.

Diller L, Packer OS, Verweij J, McMahon MJ, Williams DR, Dacey DM 
(2004) L and $\mathrm{M}$ cone contributions to the midget and parasol ganglion cell receptive fields of macaque monkey retina. J Neurosci 24:1079-1088.

Dobkins KR (2009) Does visual modularity increase over the course of development? Optom Vis Sci 86:E583-E588.

Dow BM, Gouras P (1973) Color and spatial specificity of single units in Rhesus monkey foveal striate cortex. J Neurophysiol 36:79-100.

Engel SA (2005) Adaptation of oriented and unoriented color-selective neurons in human visual areas. Neuron 45:613-623.

Felleman DJ, Xiao Y, McClendon E (1997) Modular organization of occipito-temporal pathways: cortical connections between visual area 4 and visual area 2 and posterior inferotemporal ventral area in macaque monkeys. J Neurosci 17:3185-3200.

Field GD, Sher A, Gauthier JL, Greschner M, Shlens J, Litke AM, Chichilnisky EJ (2007) Spatial properties and functional organization of small bistratified ganglion cells in primate retina. J Neurosci 27:13261-13272.

Field GD, Gauthier JL, Sher A, Greschner M, Machado TA, Jepson LH, Shlens J, Gunning DE, Mathieson K, Dabrowski W, Paninski L, Litke AM, Chichilnisky EJ (2010) Functional connectivity in the retina at the resolution of photoreceptors. Nature 467:673-677.

Fize D, Vanduffel W, Nelissen K, Denys K, Chef d'Hotel C, Faugeras O, Orban GA (2003) The retinotopic organization of primate dorsal V4 and surrounding areas: a functional magnetic resonance imaging study in awake monkeys. J Neurosci 23:7395-7406.

Friedman HS, Zhou H, von der Heydt R (2003) The coding of uniform colour figures in monkey visual cortex. J Physiol 548:593-613.

Gegenfurtner K (2001) Color in the cortex revisited. Nat Neurosci 4:339-340.

Gegenfurtner KR (2003) Cortical mechanisms of colour vision. Nat Rev Neurosci 4:563-572.

Gegenfurtner KR, Kiper DC (2003) Color vision. Annu Rev Neurosci 26:181-206.

Ghose GM, Ts'o DY (1997) Form processing modules in primate area V4. J Neurophysiol 77:2191-2196.

Gouras P (1974) Opponent-colour cells in different layers of foveal striate cortex. J Physiol 238:583-602.

Grinvald A, Lieke E, Frostig RD, Gilbert CD, Wiesel TN (1986) Functional architecture of cortex revealed by optical imaging of intrinsic signals. Nature 324:361-364.

Grünert U, Ghosh KK (1999) Midget and parasol ganglion cells of the primate retina express the alphal subunit of the glycine receptor. Vis Neurosci 16:957-966.

Hadjikhani N, Liu AK, Dale AM, Cavanagh P, Tootell RB (1998) Retinotopy and color sensitivity in human visual cortical area V8 [see comments]. Nat Neurosci 1:235-241.

Hanazawa A, Komatsu H, Murakami I (2000) Neural selectivity for hue and saturation of colour in the primary visual cortex of the monkey. Eur J Neurosci 12:1753-1763.

Harada T, Goda N, Ogawa T, Ito M, Toyoda H, Sadato N, Komatsu H (2009) Distribution of colour-selective activity in the monkey inferior temporal cortex revealed by functional magnetic resonance imaging. Eur J Neurosci 30:1960-1970.

Heimel JA, Van Hooser SD, Nelson SB (2005) Laminar organization of response properties in primary visual cortex of the gray squirrel (Sciurus carolinensis). J Neurophysiol 94:3538-3554.

Hendry SH, Reid RC (2000) The koniocellular pathway in primate vision. Annu Rev Neurosci 23:127-153.

Heywood CA, Gaffan D, Cowey A (1995) Cerebral achromatopsia in monkeys. Eur J Neurosci 7:1064-1073.

Heywood CA, Nicholas JJ, LeMare C, Cowey A (1998) The effect of lesions to cortical areas V4 or AIT on pupillary responses to chromatic and achromatic stimuli in monkeys. Exp Brain Res 122:475-480.

Hofer H, Singer B, Williams DR (2005a) Different sensations from cones with the same photopigment. J Vis 5:444-454.

Hofer H, Carroll J, Neitz J, Neitz M, Williams DR (2005b) Organization of the human trichromatic cone mosaic. J Neurosci 25:9669-9679.

Horel JA (1994) Retrieval of color and form during suppression of temporal cortex with cold. Behav Brain Res 65:165-172.

Hornstein EP, Verweij J, Schnapf JL (2004) Electrical coupling between red and green cones in primate retina. Nat Neurosci 7:745-750.

Horwitz GD, Chichilnisky EJ, Albright TD (2005) Blue-yellow signals are enhanced by spatiotemporal luminance contrast in macaque V1. J Neurophysiol 93:2263-2278.
Horwitz GD, Chichilnisky EJ, Albright TD (2007) Cone inputs to simple and complex cells in V1 of awake macaque. J Neurophysiol 97:3070-3081.

Huang PC, Mullen KT, Hess RF (2007) Collinear facilitation in color vision. J Vis 7:6 1-14.

Hubel D, Livingstone M (1990) Color puzzles. Cold Spring Harb Symp Quant Biol 55:643-649.

Hubel DH, Wiesel TN (1968) Receptive fields and functional architecture of monkey striate cortex. J Physiol 195:215-243.

Hubel DH, Wiesel TN (1977) Ferrier lecture. Functional architecture of macaque monkey visual cortex. Proc R Soc Lond B Biol Sci 198:1-59.

Hurlbert A (2003) Colour vision: primary visual cortex shows its influence. Curr Biol 13:R270-R272.

Hurlbert A (2007) Colour constancy. Curr Biol 17:R906-R907.

Huxlin KR, Saunders RC, Marchionini D, Pham HA, Merigan WH (2000) Perceptual deficits after lesions of inferotemporal cortex in macaques. Cereb Cortex 10:671-683.

Ichinose T, Lukasiewicz PD (2005) Inner and outer retinal pathways both contribute to surround inhibition of salamander ganglion cells. J Physiol 565:517-535.

Iwai E, Mishkin M (1969) Further evidence on the locus of the visual area in the temporal lobe of the monkey. Exp Neurol 25:585-594.

Jacobs GH (2008) Primate color vision: a comparative perspective. Vis Neurosci 25:619-633.

Jacobs GH, Nathans J (2009) The evolution of Primate color vision. Sci Am 300:56-63.

Jacobs GH, Williams GA, Cahill H, Nathans J (2007) Emergence of novel color vision in mice engineered to express a human cone photopigment. Science 315:1723-1725.

Johnson EN, Hawken MJ, Shapley R (2001) The spatial transformation of color in the primary visual cortex of the macaque monkey. Nat Neurosci 4:409-416.

Johnson EN, Hawken MJ, Shapley R (2004) Cone inputs in macaque primary visual cortex. J Neurophysiol 91:2501-2514.

Johnson EN, Hawken MJ, Shapley R (2008) The orientation selectivity of color-responsive neurons in macaque V1. J Neurosci 28:8096-8106.

Johnson EN, Van Hooser SD, Fitzpatrick D (2010) The representation of seconds-cone signals in primary visual cortex. J Neurosci 30:10337-10350.

Jusuf PR, Martin PR, Grünert U (2006) Random wiring in the midget pathway of primate retina. J Neurosci 26:3908-3917.

Kiper DC (2003) Colour and form in the early stages of cortical processing. J Physiol 548:335.

Klug K, Herr S, Ngo IT, Sterling P, Schein S (2003) Macaque retina contains an S-cone OFF midget pathway. J Neurosci 23:9881-9887.

Kobatake E, Tanaka K (1994) Neuronal selectivities to complex object features in the ventral visual pathway of the macaque cerebral cortex. J Neurophysiol 71:856-867.

Koida K, Komatsu H (2007) Effects of task demands on the responses of colorselective neurons in the inferior temporal cortex. Nat Neurosci 10:108-116.

Koida K, Komatsu H (2008) Impact on perceptual color judgments by microstimulation of area TE. Soc Neurosci Abstr 34:853.2.

Kolb H, Marshak D (2003) The midget pathways of the primate retina. Doc Ophthalmol 106:67-81.

Komatsu H (1998) Mechanisms of central color vision. Curr Opin Neurobiol 8:503-508.

Komatsu H, Ideura Y (1993) Relationships between color, shape, and pattern selectivities of neurons in the inferior temporal cortex of the monkey. J Neurophysiol 70:677-694.

Komatsu H, Ideura Y, Kaji S, Yamane S (1992) Color selectivity of neurons in the inferior temporal cortex of the awake macaque monkey. J Neurosci 12:408-424.

Kremers J, Lee BB, Kaiser PK (1992) Sensitivity of macaque retinal ganglion cells and human observers to combined luminance and chromatic temporal modulation. J Opt Soc Am A 9:1477-1485.

Lachica EA, Casagrande VA (1992) Direct W-like geniculate projections to the cytochrome oxidase (CO) blobs in primate visual cortex: axon morphology. J Comp Neurol 319:141-158.

Landisman CE, Ts'o DY (2002) Color processing in macaque striate cortex: relationships to ocular dominance, cytochrome oxidase, and orientation. J Neurophysiol 87:3126-3137.

Lee BB, Sun H (2009) The chromatic input to cells of the magnocellular pathway of primates. J Vis 9:15 11-18.

Lee SC, Telkes I, Grünert U (2005) S-cones do not contribute to the OFF- 
midget pathway in the retina of the marmoset, Callithrix jacchus. Eur J Neurosci 22:437-447.

Lennie P, Movshon JA (2005) Coding of color and form in the geniculostriate visual pathway (invited review). J Opt Soc Am A Opt Image Sci Vis 22:2013-2033.

Lennie P, Krauskopf J, Sclar G (1990) Chromatic mechanisms in striate cortex of macaque. J Neurosci 10:649-669.

Lennie P, Haake, Williams DR (1991) The design of chromatically opponent recetive fields. In: Computational models of visual processing (Landy MS, Movshon JA, eds) pp 71-82. Cambridge, MA: MIT.

Leventhal AG, Thompson KG, Liu D, Zhou Y, Ault SJ (1995) Concomitant sensitivity to orientation, direction, and color of cells in layers 2, 3, and 4 of monkey striate cortex. J Neurosci 15:1808-1818.

Livingstone MS, Hubel DH (1984) Anatomy and physiology of a color system in the primate visual cortex. J Neurosci 4:309-356.

Lotto RB, Chittka L (2005) Seeing the light: illumination as a contextual cue to color choice behavior in bumblebees. Proc Natl Acad Sci U S A 102:3852-3856.

Lu HD, Roe AW (2008) Functional organization of color domains in V1 and V2 of Macaque monkey revealed by optical imaging. Cereb Cortex 18:516-533.

Mancuso K, Hauswirth WW, Li Q, Connor TB, Kuchenbecker JA, Mauck MC, Neitz J, Neitz M (2009) Gene therapy for red-green colour blindness in adult primates. Nature 461:784-787.

Mancuso K, Mauck MC, Kuchenbecker JA, Neitz M, Neitz J (2010a) A multi-stage color model revisited: implications for a gene therapy cure for red-green colorblindness. Adv Exp Med Biol 664:631-638.

Mancuso K, Neitz M, Hauswirth WW, Li Q, Connor TB, Kuchenbecker JA, Mauck MC, Neitz J (2010b) Long-term results of gene therapy for redgreen colorblindness in monkeys. Invest Ophthalmol Vis Sci 51:EAbstract 6292.

Mangel SC (1991) Analysis of the horizontal cell contribution to the receptive field surround of ganglion cells in the rabbit retina. J Physiol 442:211-234.

Martin PR, White AJ, Goodchild AK, Wilder HD, Sefton AE (1997) Evidence that blue-on cells are part of the third geniculocortical pathway in primates. Eur J Neurosci 9:1536-1541.

Martin PR, Lee BB, White AJ, Solomon SG, Rüttiger L (2001) Chromatic sensitivity of ganglion cells in the peripheral primate retina. Nature 410:933-936.

Matsumora T, Koida K, Komatsu H (2008) Relationship between color discrimination and neural responses in the inferior temporal cortex of the monkey. J Neurophysiol 100:3361-3374.

Michael CR (1978) Color vision mechanisms in monkey striate cortex: dual-opponent cells with concentric receptive fields. J Neurophysiol 41:572-588.

Mollon JD (2009) A neural basis for unique hues? Curr Biol 19:R441-R442; author reply R442-R443.

Murphey DK, Yoshor D, Beauchamp MS (2008) Perception matches selectivity in the human anterior color center. Curr Biol 18:216-220.

Neitz M, Neitz J, Jacobs GH (1991) Spectral tuning of pigments underlying red-green color vision. Science 252:971-974.

Ohki K, Chung S, Kara P, Hübener M, Bonhoeffer T, Reid RC (2006) Highly ordered arrangement of single neurons in orientation pinwheels. Nature 442:925-928.

Osorio D, Vorobyev M (2008) A review of the evolution of animal colour vision and visual communication signals. Vision Res 48:2042-2051.

Packer OS, Verweij J, Li PH, Schnapf JL, Dacey DM (2010) Blue-yellow opponency in primate $S$ cone photoreceptors. J Neurosci 30:568-572.

Percival KA, Jusuf PR, Martin PR, Grünert U (2009) Synaptic inputs onto small bistratified (blue-ON/yellow-OFF) ganglion cells in marmoset retina. J Comp Neurol 517:655-669.

Reid RC, Shapley RM (2002) Space and time maps of cone photoreceptor signals in macaque lateral geniculate nucleus. J Neurosci 22:6158-6175.

Roorda A, Metha AB, Lennie P, Williams DR (2001) Packing arrangement of the three cone classes in primate retina. Vision Res 41:1291-1306.

Roy S, Jayakumar J, Martin PR, Dreher B, Saalmann YB, Hu D, Vidyasagar TR (2009) Segregation of short-wavelength-sensitive (S) cone signals in the macaque dorsal lateral geniculate nucleus. Eur J Neurosci 30:1517-1526.

Schiller PH, Finlay BL, Volman SF (1976) Quantitative studies of single-cell properties in monkey striate cortex. I. Spatiotemporal organization of receptive fields. J Neurophysiol 39:1288-1319.

Shapley R (2009) Vision: gene therapy in colour. Nature 461:737-739.
Shapley R, Hawken M (2002) Neural mechanisms for color perception in the primary visual cortex. Curr Opin Neurobiol 12:426-432.

Shevell SK, Kingdom FA (2008) Color in complex scenes. Annu Rev Psychol 59:143-166.

Sincich LC, Horton JC (2005) The circuitry of V1 and V2: integration of color, form, and motion. Annu Rev Neurosci 28:303-326.

Solomon SG, Lennie P (2005) Chromatic gain controls in visual cortical neurons. J Neurosci 25:4779-4792.

Solomon SG, Lennie P (2007) The machinery of colour vision. Nat Rev Neurosci 8:276-286.

Solomon SG, Peirce JW, Lennie P (2004) The impact of suppressive surrounds on chromatic properties of cortical neurons. J Neurosci 24:148-160.

Srinivasan MV (2010) Honey bees as a model for vision, perception, and cognition. Annu Rev Entomol 55:267-284.

Stepniewska I, Collins CE, Kaas JH (2005) Reappraisal of DL/V4 boundaries based on connectivity patterns of dorsolateral visual cortex in macaques. Cereb Cortex 15:809-822.

Stockman A, Brainard DH (2010) Color vision mechanisms. In: The OSA handbook of optics, Ed 3 (Bass M, ed) pp 11.11-11.104. New York: McGraw-Hill.

Stoughton CM, Conway BR (2008) Neural basis for unique hues. Curr Biol 18:R698-R699.

Sumner P, Anderson EJ, Sylvester R, Haynes JD, Rees G (2008) Combined orientation and colour information in human V1 for both L-M and S-cone chromatic axes. Neuroimage 39:814-824.

Sun H, Smithson HE, Zaidi Q, Lee BB (2006) Do magnocellular and parvocellular ganglion cells avoid short-wavelength cone input? Vis Neurosci 23:441-446.

Szmajda BA, Grünert U, Martin PR (2008) Retinal ganglion cell inputs to the koniocellular pathway. J Comp Neurol 510:251-268.

Tailby C, Solomon SG, Lennie P (2008) Functional asymmetries in visual pathways carrying S-cone signals in macaque. J Neurosci 28:4078-4087.

Thorell LG, De Valois RL, Albrecht DG (1984) Spatial mapping of monkey V1 cells with pure color and luminance stimuli. Vision Res 24:751-769.

Tootell RB, Hadjikhani N (1998) Reply to "Has a new color area been discovered" [Letter to Editor]. Nat Neurosci 1:335-336.

Tootell RB, Nelissen K, Vanduffel W, Orban GA (2004) Search for color 'center(s)' in macaque visual cortex. Cereb Cortex 14:353-363.

Ts'o DY, Gilbert CD (1988) The organization of chromatic and spatial interactions in the primate striate cortex. J Neurosci 8:1712-1727.

Valberg A (2001) Unique hues: an old problem for a new generation. Vision Res 41:1645-1657.

Van Essen DC, Felleman DJ, DeYoe EA, Olavarria J, Knierim J (1990) Modular and hierarchical organization of extrastriate visual cortex in the macaque monkey. Cold Spring Harb Symp Quant Biol 55:679-696.

Van Hooser SD, Nelson SB (2006) The squirrel as a rodent model of the human visual system. Vis Neurosci 23:765-778.

Vautin RG, Dow BM (1985) Color cell groups in foveal striate cortex of the behaving macaque. J Neurophysiol 54:273-292.

Vladusich T (2007) Chromatic aberration and the roles of double-opponent and color-luminance neurons in color vision. Neural Netw 20:153-155.

Wachtler T, Sejnowski TJ, Albright TD (2003) Representation of color stimuli in awake macaque primary visual cortex. Neuron 37:681-691.

Wässle H, Dacey DM, Haun T, Haverkamp S, Grünert U, Boycott BB (2000) The mosaic of horizontal cells in the macaque monkey retina: with a comment on biplexiform ganglion cells. Vis Neurosci 17:591-608.

Webster MA (2009) Calibrating color vision. Curr Biol 19:R150-R152.

Wiesel TN, Hubel DH (1966) Spatial and chromatic interactions in the lateral geniculate body of the rhesus monkey. J Neurophysiol 29:1115-1156.

Xiao Y, Casti A, Xiao J, Kaplan E (2007) Hue maps in primate striate cortex. Neuroimage 35:771-786.

Yasuda M, Banno T, Komatsu H (2010) Color selectivity of neurons in the posterior inferior temporal cortex of the macaque monkey. Cereb Cortex 20:1630-1646.

Zeki S (1980) The representation of colours in the cerebral cortex. Nature 284:412-418.

Zeki S, Marini L (1998) Three cortical stages of colour processing in the human brain. Brain 121:1669-1685.

Zeki S, Shipp S (1989) Modular Connections between areas V2 and V4 of macaque monkey visual cortex. Eur J Neurosci 1:494-506.

Zeki S, McKeefry DJ, Bartels A, Frackowiak RS (1998) Has a new color area been discovered? [Letter to Editor]. Nat Neurosci 1:335.

Zhou H, Friedman HS, von der Heydt R (2000) Coding of border ownership in monkey visual cortex. J Neurosci 20:6594-6611. 